\title{
Comments on waste to energy technologies in the United Arab Emirates (UAE)
}

\author{
Zarook Shareefdeen ${ }^{\dagger}$, Norhan Youssef, Ahmed Taha, Catherine Masoud \\ Department of Chemical Engineering, American University of Sharjah, P.O. Box 26666, Sharjah, UAE
}

\begin{abstract}
The main reason that drives many developing countries to pursue waste-to-energy (WtE) technologies is that it produces energy while eliminating build-up of large quantities of wastes, at a time, when oil and gas reserves are declining. The rate of generation of municipal solid wastes (MSW) in any given country depends on many factors including economy, population, and modernization of industry and infrastructure developments. The United Arab Emirates (UAE) is a federation of seven emirates that has grown to be one of the Middle East's most important economic centers. UAE has also become one of the highest waste producing countries due to fast development and growth; thus, UAE pursue modern technologies to covert generated wastes into energy. In this communication, the status of on-going waste to energy projects and WtE plants that are currently under design and construction in UAE are discussed. The need for development of WtE technologies is presented based on the literature, reports, economics and the environmental regulations.
\end{abstract}

Keywords: Gasification, Municipal solid waste, MSW, Pyrolysis, Waste-to-energy

\section{Introduction}

The earliest and most common application of waste-to-energy (WtE) technology is the production of electricity from incineration of municipal solid wastes (MSW). The rate of generation of MSW in any given country depends on its economy. As more and more of the third world countries move towards modernization, the generation of MSW will continue to increase. A study in 2012 by the World Bank indicates that around 1.3 billion tons of MSW are produced every year, at an average of $1.2 \mathrm{~kg} / \mathrm{capita} / \mathrm{d}$. It is important to note that the per capita MSW generation rate in the UAE is between 1.76 to $2.3 \mathrm{~kg} / \mathrm{d}$, which is higher and comparable to average American who generates about $2.1 \mathrm{~kg}$ of waste/d [1]. Rana et al. [2] presented an overview of generation, collection, transportation, treatment and disposal of solid waste management (SWM) practices in Chandigarh, India [2]. They report the daily average generation of solid waste was $0.267 \mathrm{~kg} / \mathrm{capita} / \mathrm{d}$ which is much lower than UAE waste generation rate. They report several drawbacks in the SWM system including untrained work force, haphazard collection practice and lack of collection vehicles [2]. Therefore, the actual generation rate can be much higher than the reported value of $0.267 \mathrm{~kg} / \mathrm{capita} / \mathrm{day}$. In another study [3],
Rana et al. report that the city aims to produce refuse derived fuel (RDF) from solid wastes [3].

Adefeso et al. [4] report that from the combustible components of MSW, RDF can be produced through drying and compression. Production process of RDF involves segregating, crushing and mixing. RDF pellets are easier to be handled and stored. RDF are produced in many forms such as coarse, fluff and powder. Use of RDF gives better energy recovery as compared to raw MSW. When compared to MSW, RDF pellets are more uniform, has higher heating value and lower moisture level. By using RDF, hydrogen-rich synthesis gas can be produced through gasification. RDF gasification substantially reduces corrosion and emissions of pollutants such as sulphur gases, chlorine and heavy metal particles [4].

The amounts and composition of wastes vary significantly from country to country and city to city. For example, Rana et al [5], characterized physical and chemical properties of the MSW generated in three locations for different socio-economic groups. The results showed that biodegradable content varied from $42.6 \%-52.0 \%$ and inert fraction was around $28 \%$. The moisture content varied from $40 \%-50 \%$ and energy content varied from $1,542 \mathrm{kcal} / \mathrm{kg}$ to $1929 \mathrm{kcal} / \mathrm{kg}$. Rana et al [5] proposed alternatives to the existing
This is an Open Access article distributed under the terms of the Creative Commons Attribution Non-Commercial License (http://creativecommons.org/licenses/by-nc/3.0/) which permits unrestricted non-commercial use, distribution, and reproduction in any medium, provided the original work is properly cited.

Copyright (C) 2020 Korean Society of Environmental Engineers
Received November 3, 2018 Accepted February 24, 2019

${ }^{\dagger}$ Corresponding author

Email: zshareefdeen@aus.edu

Tel: +00971-6515-2988

ORCID: 0000-0001-5051-2504 
MSW management practices. The proposed methods include composting, vermicomposting, recycling, bio-methanation RDF plants as a comprehensive MSW system [5]. Similarly, Sharma et al. evaluated existing solid waste management practices at four different locations in India using the 'wasteaware' benchmark indicators for comparing the efficiency of MSW management system [6].

Composting or vermicomposting also substantially reduce the quantity of wastes. Hanc et al. [7] studied the effect of composting and vermicomposting processes on the distribution of particles into size fractions. Composting processes convert organic wastes into useful products such as soil amendments. Composting is referred to as the controlled aerobic conversion of wastes and vermicomposting involves bio-oxidation and stabilization by action of earthworms and microorganisms [7]. It is the microorganisms which degrade the organic waste and the earthworms promote aeration conditions, thereby increase the microbial activity from various feedstocks. They report vermicomposting produces finer and more homogeneous product as compared to composting [7].

The development and implementation of WtE technologies in developing countries has become inevitable. The main reason that drives many developing countries to pursue WtE technologies instead of composting or other methods is that it produces energy while eliminating buildup of wastes, at a time, when oil and gas reserves are declining. According to World Energy Council [8], WtE technology encompasses "any waste treatment process that creates energy in the form of electricity, heat or transport fuels from a waste source." Furthermore, WtE technologies reduce waste that would contribute to greenhouse gas emissions from landfills [9]. Cost of producing energy from waste ( $\$ 93 / \mathrm{MWh}$ ) is much lower as compared to energy produced from other renewable sources such as solar power (\$234/MWh) [1].

The market for $\mathrm{WtE}$ is continuing to grow despite the economic depressions. The total global market value of WtE industry was \$24 billion in 2012 with an annual compounded growth rate of $5.5 \%$. The global $\mathrm{WtE}$ market is significant and it is expected to increase to $\$ 35.5$ billion by 2019 [9]. There are other factors that contribute to this high growth rate, namely the growing costs of energy production, environmental dangers posed by hazardous wastes, and a shift in the policies and legislature of developed countries towards favoring WtE. Decreasing landfill space and energy security are also two key factors that drive WtE market [9]. As more countries enter the market, WtE technology is expected to advance even more and the associated costs of WtE technologies will reduce even further. Table 1 lists the production capacities of the leading countries in WtE technology [8]. It is important to note that the growth of the WtE market is influenced by the increase in usage and improved efficiencies of existing processes, as well as innovation in the development of WtE technologies [8].

The objective of this communication is to provide the status of on-going WtE projects and WtE plants that are currently under design and construction in UAE.

\section{An Overview of Waste to Energy Technologies}

WtE technologies can be broadly classified into thermal and biochemical methods. Commercial WtE technologies include incineration, pyrolysis, gasification, thermal de-polymerization, plasma arc gasification, anaerobic digestion, mechanical and biological treatment [9]. Recent advances in WtE technologies also include isothermal expansion of sodium [10]; this technology uses high-energy electrons emitted from nuclear by-products and solid-state devices that directly convert heat to electricity. With mixed wastes as input, simple incineration is often utilized by means of a combined heat and power (CHP) plant. It is the most developed WtE technology as well as the first WtE technology used in most countries. When high percentage of organics is present in the MSW, incineration is not a suitable technique.

One of the most efficient incineration plants, Afval Energie Bedrijf CHP plant located in Amsterdam, can process 1.5 million tons of MSW annually at an efficiency of 30\% [8]. According to world health organization (WHO), waste that can undergo incineration should have the following properties: (a) moisture content, 30\% (b) minimum heating value, $8,370 \mathrm{~kJ} / \mathrm{kg}$ (c) fraction of combustible materials, $60 \%$ (d) fraction of non- combustible materials $<5 \%$ and (e) fraction of non- combustible fines $<20 \%$. There is also a restriction on the types of wastes used, for example reactive chemical waste, waste with a high proportion of heavy metals, plastics and pressurized gas containers cannot be incinerated. Although incineration transforms waste into less hazardous materials and decreases the volume by ten folds, this technology still produces a large amount of pollutants [11]. The flue gas can contain pollutants such as dust, hydrochloric acid, hydrofluoric acid, sulphur dioxide, nitrogen oxides, dioxins and heavy metals [12]. A

Table 1. Production Capacities of Leading Countries in WtE Technology [8]

\begin{tabular}{|c|c|c|c|c|c|}
\hline Country & $\begin{array}{l}\text { Quantity of raw } \\
\text { waste }\end{array}$ & $\begin{array}{c}\text { Electricity } \\
\text { Generation Capacity }\end{array}$ & $\begin{array}{c}\text { Annual Electricity } \\
\text { Generation }\end{array}$ & $\begin{array}{l}\text { Direct Use from } \\
\text { Combustion }\end{array}$ & $\begin{array}{c}\text { Total Energy } \\
\text { Production }\end{array}$ \\
\hline & (million tonnes) & $(\mathrm{kW})$ & (T) & (T) & (T) \\
\hline Canada & 11.856 & 211,187 & & 1.688 & \\
\hline France & & 772,800 & 13,586 & 27,209 & 40,795 \\
\hline Germany & 0.94 & 852,000 & 11,200 & & \\
\hline Japan & 0.601 & $2,230,000$ & & & \\
\hline Singapore & & 135,000 & 3,994 & & \\
\hline United Kingdom & 3.8 & 375,900 & 7,061 & 2,108 & 9,169 \\
\hline United States of America & 254 & $2,669,000$ & 54,255 & 20,833 & 75,088 \\
\hline
\end{tabular}




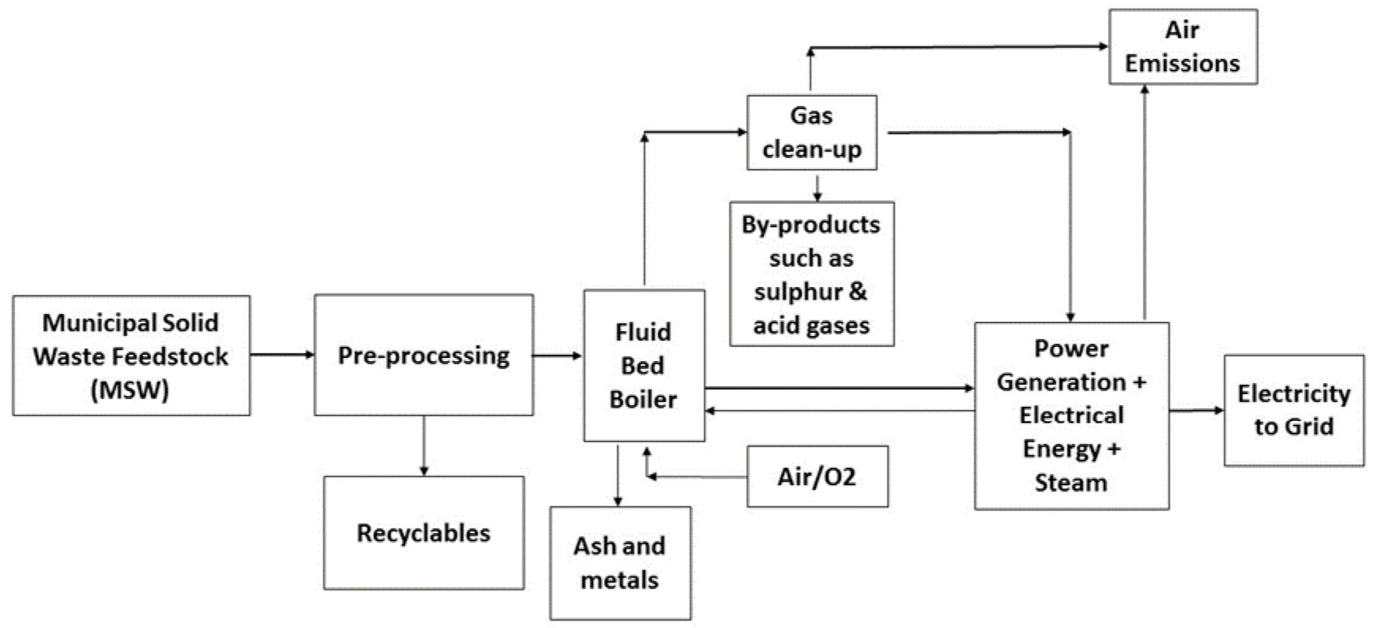

Fig. 1. Schematic of the process from MSW to electricity via incineration [13].

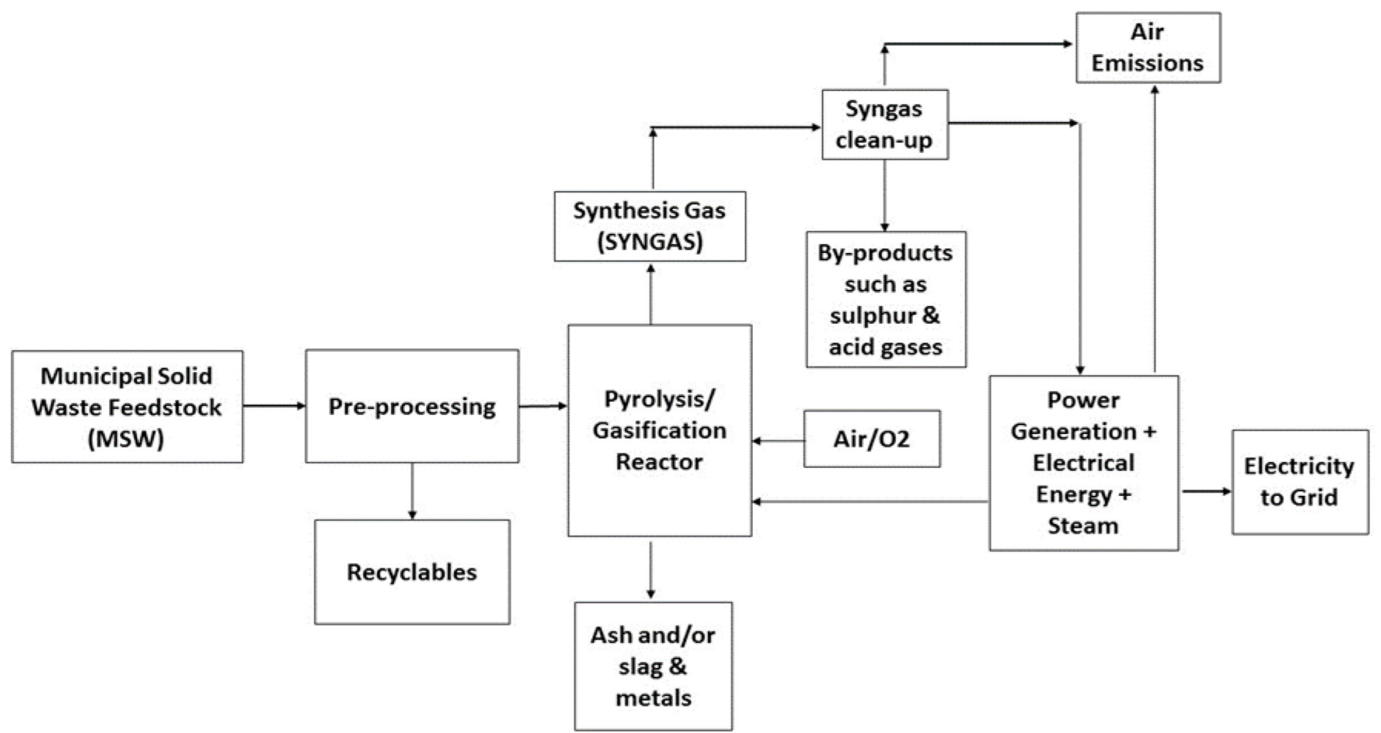

Fig. 2. Schematic of the process from MSW to electricity via pyrolysis/gasification [13].

brief schematic of the process of converting MSW to electricity generation is given in Fig. 1 [13].

Gasification refers to the incomplete combustion of a solid material to produce a gaseous fuel that can be used to generate energy [14]. Gasification takes place in an oxygen-controlled environment. The by-products of gasification are mainly methane and trace amounts of higher hydrocarbons. The effluent stream is called syngas, wood gas, biogas or by other names depending on the nature of the wastes being gasified. Gasification is a much cleaner approach than incineration. The disadvantages of gasification include the cost of cleaning the reactor from produced tars and residue as well as the repeated interruptions of the operation. Furthermore, the presence of moisture in the waste reduces the efficiency; thus the solid wastes have to be pre-treated before gasification.

Pyrolysis is another thermal process that requires heat energy to decompose carbon-containing compounds materials into syn- thesis gas, oil and char in an oxygen free environment. Gasification usually follows pyrolysis where the unreacted hydrocarbons in the pyrolysis gas are further degraded [15]. In a pyrolysis study, Noma et al. [16] showed $99.3 \%$ recovery with the valuable materials such as metal, char and clean gas. The volume reduction of the waste after treatment was $1 / 190$. The pre-treatment steps prior to pyrolysis include sorting of the raw materials and dehydration. Chen et al. [17] state that there are many factors that affect the resulting products of pyrolysis. Typical temperature of pyrolysis ranges from $300^{\circ} \mathrm{C}$ to $900^{\circ} \mathrm{C}$. If the temperatures were from $500^{\circ} \mathrm{C}$ to $550^{\circ} \mathrm{C}$, then the majority of the product would be liquid. If the temperature exceeds $700^{\circ} \mathrm{C}$, then the majority of the product is syngas. Typical residence time ranges from a few seconds to several hours. The longer the residence time, the more tar will undergo cracking and therefore more syngas will be produced. Upon completion of pyrolysis, the gas product could undergo gas- 
ification in order to produce a higher proportion of syngas or gas could be directly used. Furthermore, the solid products of pyrolysis such as char undergo screening, quenching and separation. If the gas undergoes gasification, then there are two types of gasification: low-temperature and high-temperature gasification. Low temperature gasification occurs at a temperature range of $700^{\circ} \mathrm{C}$ to $1,000^{\circ} \mathrm{C}$ and at this range, the product gas contains high content of hydrocarbons [18]. High temperature gasification occurs at a temperature range of $1,200^{\circ} \mathrm{C}$ to $1,600^{\circ} \mathrm{C}$ where the product gas has a low content of hydrocarbons, but a high content of $\mathrm{CO}$ and $\mathrm{H}_{2}$, which is termed as syngas. According to Drift and Boerrigter [19], syngas could be used to generate fuel or could be used to produce other compounds such as dimethyl ether that are needed for petrochemical processes. A brief schematic of the process for a combined gasification/pyrolysis plant is shown in Fig. 2 [13].

Masdar Institute, a research facility located in the Emirates of Abu Dhabi (UAE), is making advances in the use of dark fermentation from MSW to produce biodiesel. The results suggest that biogas produced from waste could generate $18 \mathrm{MW} / \mathrm{y}$ for Abu Dhabi, which would help the goal of generating $7 \%$ of its power from renewable sources by 2020 [20]. Research projects are in progress in several areas of research including microbial desalination, and production of biodiesel from discarded restaurant oils. UAE has ambitious plans to serve as the headquarters of International Renewable Energy Agency (IRENA) [21].

\section{Waste to Energy Technologies in the United Arab Emirates (UAE)}

\subsection{Waste Generation in the United Arab Emirates (UAE)}

UAE has registered an unprecedented growth in its GDP over the last decade, owing to the staggering expansion of the oil and gas industry in the capital Abu Dhabi, as well as the tourism market in Dubai. The GDP per capita of a nation is a figure that is strongly correlated to the rate of solid waste production [22]. The UAE is one of the world's highest producers of MSW per capita. A government statistic reports 26 million tons of waste is generated in the UAE in 2012 [23]. In the emirate of Abu Dhabi, statistical analysis conducted by different authorities reported that average annual per capita waste generation is 1.76 to $2.3 \mathrm{~kg} /$ day/person. These numbers are almost twice the figure of the UK. Using the conservative estimate of $1.76 \mathrm{~kg} /$ day/person and projecting the estimated increase in population, Fig. 3 shows the expected trend of solid waste generation in Abu Dhabi [22]. This worrying trend could severely strain the country's infrastructure and ability to manage waste. The country has decided to adopt European standards in waste management and $\mathrm{WtE}$ technologies are to be employed in order to achieve the set target by 2030 [24].

As in any place, the composition of solid waste in the UAE varies widely by source and region. However, it is estimated that exactly half of the entire waste generated in the country is construction and demolition waste, which is not compatible with most WtE technologies. To combat this major constituent of the waste, the Environmental Agency has developed regulations, which sets a minimum required recycling target for construction and demoli- tion waste of $30 \%$ with a reward mechanism for achieving higher recycling rates set at $50 \%$ and $70 \%$, respectively. Another constraint it places on construction companies is that they must ensure adequate waste handling and transportation facilities are in place [24].

Grycová et al. [25] report a study on the conversion of food wastes into energy using pyrolysis process. Coker [26] reports a study on conversion of food waste into biogas energy and fertilizer using an anaerobic digestion. Food waste is another major source of waste specifically in the emirate of Dubai (UAE) where food waste accounts for $55 \%$ of the emirate's waste. The EPA also had introduced an initiative specific to this problem in collaboration with the humanitarian Red Crescent Organization. The regulation puts the Red Crescent in charge of leftover food from restaurants, hotels and wedding halls, where they work to preserve its quality until it is delivered to the needy [24]. A study reveals (Fig. 4), the following average composition of MSW in Abu Dhabi [22].

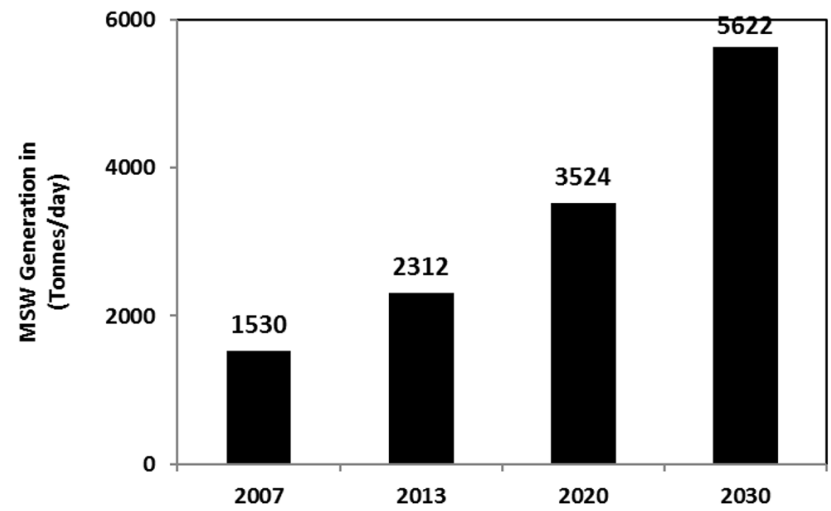

Fig. 3. Expected trend of MSW growth in Abu Dhabi (UAE).

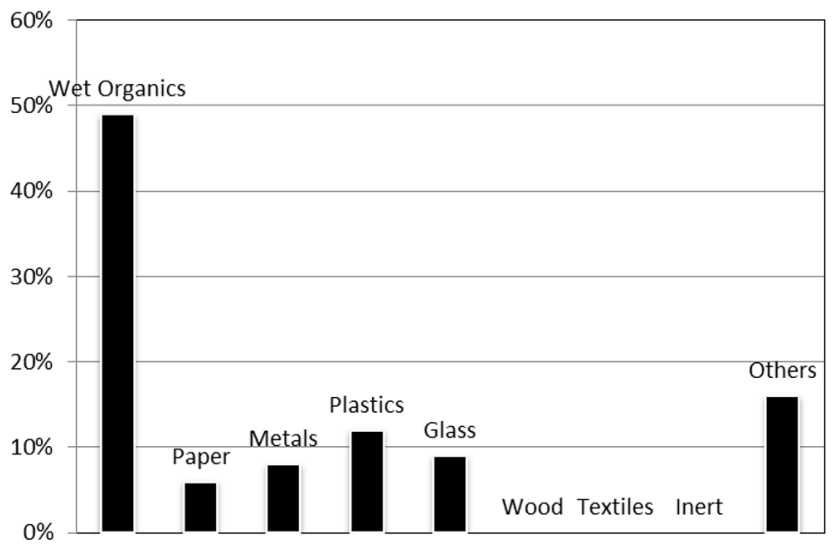

Fig. 4. Composition of MSW (Abu Dhabi, UAE).

\subsection{UAE Regulations on Waste Management}

The regulations on waste management were issued in September 2005 and the law ensures waste generators are responsible for segregating, identifying the non-hazardous and hazardous components, as well as contracting with approved private disposal and treatment facilities. The centre of waste management (CWM) is the competent authority responsible for handling waste manage- 
ment issues and CWM specifies the technical guidelines necessary to meet the law, as well as lists the procedures for periodic inspections and audits for all waste generation and disposal facilities. The CWM came up with an integrated Environmental Health and Safety Management System (EHSMS) that co-ordinates with other authorities, namely transport, energy, health and tourism. CWM has licensed WtE as a feasible method of treatment of waste [27].

\subsection{Waste to Energy Initiatives in UAE}

Several institutions are adopting the WtE initiatives in the UAE. The main ones include TAQA, (Abu Dhabi, UAE based Energy Company) and Bee'ah (Sharjah, UAE based environmental company). TAQA is expected to have an operational incineration plant [28] and Bee'ah plans a construction of a pyrolysis and gasification plant [29]. According to Todorova [28], TAQA plans to construct two WtE plants and it plans to process one million tonnes/y of waste that contains $50 \%$ organics and $50 \%$ paper, cardboard and wood. TAQA expects that the energy extracted from the waste could be used to power 20,000 homes in Abu Dhabi [30]. The plant is projected to eliminate the discharge of more than one million tonnes of $\mathrm{CO}_{2}$ per year, and will also provide the capability of recycling metal parts and reusing ashes in the construction industry. According to Masdar Institute [20], the electricity generated from the biogas and compost could earn Abu Dhabi around 30 million dollars, and at the same time help meet Abu Dhabi's near-zero waste goal.

Bee'ah, on the other hand, plans to construct a different waste to energy plant that utilises pyrolysis and gasification [28]. According to Bee'ah, the facility will process around 400,000 tonnes per year with an output of about $85 \mathrm{MW}$, which will provide power to an estimated number of 50,000 homes, and will also help the city to achieve its vision of $100 \%$ landfill diversion [29]. Even though both companies share a common vision of reduction of waste, different WtE technologies are employed; TAQA has opted for incineration and Bee'ah on the other hand has selected gasification/pyrolysis technology [28].

Furthermore, in January of 2016, Bee'ah and Masdar (Abu Dhabi's renewable energy company) announced their plans to collaborate and co-develop more WtE initiatives in Sharjah, UAE and the region. The partnership will combine Bee'ah's innovative recycling technologies with Masdar's know-how on energy generation and to realise at least two more WtE plants to be constructed by 2021 [31].

As for the emirate of Dubai, in June 2016, Dubai Municipality announced its plans to establish the largest solid WtE facility in the Middle East. The facility will take about $3 \mathrm{y}$ to construct, with operations planned to commence in the second quarter of 2020. The plant is expected to produce $60 \mathrm{MW}$ of power from the 2,000 metric tonnes of MSW per day, in its first phase of operation. The move comes in line with the national agenda to decrease landfill use by $75 \%$ by the year 2021 , and to protect the environment from methane gas emissions from landfills [32]. The greatest challenge that the $\mathrm{WtE}$ industry faces at this point is due to the low cost of dumping waste into landfills; accordingly, in an effort to reduce landfill use, Dubai Municipality will begin to charge waste generators higher fees based on the weight and the type of waste disposed [33].

\section{Conclusions}

In conclusion, waste to energy technologies are a great step towards decreasing the amount of waste disposed into landfills, while simultaneously generating energy that could be used as a source of power or heat. This alternative source of energy reduces the strain on the consumption of oil and fossil fuels. In addition, diverting waste from landfills decreases health hazards associated with the accumulation of waste, as well as decreases the amount of pollutants emitted into the environment. The UAE is taking a timely step in diverting waste from landfills using two WtE technologies: Incineration and pyrolysis with gasification. In this communication, waste generation, regulation and current steps taken to convert $\mathrm{WtE}$ in the different emirates (Abu-Dhabi, Sharjah and Dubai) of the UAE are discussed.

\section{References}

1. Dann C, Vandenberg J, Thota P, Stillman J. Reconsidering waste-to-energy. Public Utilities Fortnightly 2012:150:44-51.

2. Rana Y, Ganguly R, Gupta A. Evaluation of solid waste management in satellite towns of Mohali and Panchkula. J. Waste Technol. Manage. 2017:43;280-294.

3. Rana Y, Ganguly R, Gupta A. An Assessment of solid waste management system in Chandigarh City. Electron. J. Geotechnical Eng. 2015:20;1547-1572.

4. Adefeso I, Rabiu AM, Ikhu-Omoregbe D. Refuse-derived fuel gasification for hydrogen production in high temperature proton exchange membrane fuel cell base CHP system. Waste Biomass Valor. 2015;6:967-974.

5. Rana Y, Ganguly R, Gupta AK. Physico-chemical characterization of municipal solid waste from Tricity region of Northern India: A case study. J. Mater. Cycles Waste Manage. 2018:20; 678-689.

6. Sharma A, Ganguly R, Gupta AK. Matrix method for evaluation of existing solid waste management system in Himachal Pradesh, India. J. Mater. Cycles Waste Manage. 2018:20;1813-1831.

7. Hanc A, Dreslova M. Effect of composting and vermicomposting on properties of particle size fractions. Bioresour. Technol. 2016;217:186-189.

8. World Energy Council. Waste to Energy 7b [Internet]. c2013. Available from: https:/www.worldenergy.org/wp-content/uploads/2013/10/WER_2013_7b_Waste_to_Energy.pdf.

9. Agnani M. Thermal and biological waste-to-energy markets. Am. Ceram. Soc. Bull. 2017;96:8-8.

10. El-Shahat A. Recent advances in waste-to-energy. Nat. Gas Electricity 2017;33:19-24.

11. Buekens A. Waste Incineration Technology. In: Nath B and Cholakov G, eds. Pollut. Control Technol. 2009;2:399-421.

12. Waste Management Resources: Incineration [Internet]. [cited 1 October 2015]. Available from: http://www.wrfound.org.uk/articles/incineration.html.

13. Young G. Municipal solid waste to energy conversion processes: Economic, technical, and renewable comparisons. Hoboken: John Wiley \& Sons; 2010. 
14. Shareefdeen Z, Elkamel A, Tse S. Review of current technologies used in municipal solid waste-to-energy facilities in Canada. CLEAN. Technol. Environ. Policy 2015;17:1837-1846.

15. Friends of the Earth. Pyrolysis and gasification and plasma friends of the earth [Internet]. c2002 [cited 1 October 2015]. Available from: https://mysite.wsu.edu/personal/gmwaniki/ biofuels/Related\%20documents/gasification_pyrolysis.pdf.

16. Noma T, Ide K, Yoshikawa J, et al. Development of waste gasification and gas reforming system for municipal solid waste (MSW). J. Mater. Cycles Waste Manage. 2012:14:153-161.

17. Chen D, Yin L, Wang H, He P. Pyrolysis technologies for municipal solid waste: A review. Waste Manage. 2015:37:116:2466-2486.

18. Chhiti Y, Kemiha M. Thermal conversion of biomass, pyrolysis and gasification: A review. Intl. J. Eng. Sci. 2013:2:75-85.

19. Drift A, Boerrigter H. Synthesis gas from biomass for fuels and chemicals [Internet]. Available from: http://www.ecn.nl/ docs/library/report/2006/c06001.pdf.

20. The National. How Abu Dhabi's waste can help energy and farming [Internet]. c2014. [cited 19 February 2015]. Available from: http://www.thenational.ae/uae/science/masdar-institutehow-abu-dhabis-waste-can-help-energy-and-farming.

21. Madichie NO. Irena - Masdar City (UAE) - Exemplars of Innovation into Emerging Markets. Foresight: J. Futures Stud. Strategic Thinking and Policy 2011:13:34-47.

22. Somasundaram R. Potential for waste to energy facilities in Abu Dhabi [Internet]. c2015 [cited 1 October 2015]. Available from: http://www.iswa.org/uploads/tx_iswaknowledgebase/5-240 paper_long.pdf.

23. The National. The UAE's war on waste [Internet]. In: Bustani H eds. c2014 [cited 17 June 2015]. Available from: http://www. thenational.ae/uae/environment/the-uaes-war-on-waste\#full.

24. Environment Agency - Abu Dhabi. Towards integrated waste management in Abu Dhabi [Internet]. c2013. [cited 18 June
2015] Available from: http://www.ead.ae/wp-content/uploads/ 2014/03/ Waste-PB-Eng.pdf.

25. Grycová B, Koutník I, Pryszcz A, Kaloč M. Application of pyrolysis process in processing of mixed food wastes. Polish J. Chem. Technol. 2016:18:19-23.

26. Coker C. Food waste to renewable natural gas. BioCycle 2017:58:41-42.

27. Banerjee U. Waste management approach in the emirate of Abu Dhabi (Focus waste to energy). In: Global sustainable cities network; 21-23 January 2014; Abu Dhabi.

28. The National. UAE turns to waste burning to produce greener energy. In: Todorova V, eds. Abu Dhabi: The National; 2014.

29. GulfNews. Sharjah Waste-to-Energy plant to divert all waste from landfill. In: Masudi F, eds. c2016 [cited 3 October 2016]. Available from: https://gulfnews.com/uae/environment/sharjahwaste-to-energy-plant-to-divert-all-waste-from-landfill-1.1657165.

30. Gulfbusiness. Transforming the UAE's waste to energy. In: Saadi D, eds. c2014 [cited 19 February 19 2014]. Available from: http:/gulfbusiness.com/2014/05/wasted-dollars/\#.VOW8J PmUe9U.

31. Masdar.ae. Masdar and Bee'ah to partner on waste to energy initiatives in region. c2016 [cited 4 October 2016]. Available from: http://www.masdar.ae/en /media/detail/masdar-and-beeahto-partner-on-waste-to-energy-initiatives-in-region.

32. ArabianIndustry.com. Dubai to construct $\$ 544 \mathrm{~m}$ waste-to-energy plant. In: Bhatia N, eds. c2016 [cited 3 October 3 2016] Available from: http://www.arabianindustry.com/ construction/ news/2016/jun/21/dubai-to-construct-544m-waste-to-energy-plant-5413733/.

33. The National. Dubai municipality mulls increased landfill charges. In: Todorova V, eds. c2015 [cited 3 October 2016]. Available from http://www.thenational.ae/ uae/dubai-municipality-mulls-increased-landfill-charges. 